\title{
BIOLOGICAL EFFECTS OF METAL NANOPARTICLES AFTER EXPOSURE OF MAMMALIAN CELLS
}

\author{
${ }^{1}$ Olga D. HENDRICKSON, ${ }^{2}$ Sergey A. PUKHOV, ${ }^{1,2}$ Anatoly V. ZHERDEV \\ ${ }^{1}$ Bach Institute of Biochemistry, Research Center of Biotechnology of the Russian Academy of Sciences, \\ Moscow, Russian Federation, odhendrick@gmail.com \\ ${ }^{2}$ Institute of Physiologically Active Compounds, Russian Academy of Sciences, Moscow, \\ Russian Federation, zherdev@inbi.ras.ru
}

https://doi.org/10.37904/nanocon.2019.8495

\begin{abstract}
Investigations of the biological effects of nanomaterials are important for assessing the risk of nanotechnology products. The present study includes the comparative investigation of the localization of core-shell gold hybrid nanostructures and native titanium dioxide nanoparticles. Changes in biochemical parameters of the treated rats in comparison to control animals were observed depending on the type of nanoparticles used. The exposure did not cause lethality, substantial behavior deviations, water and food consumption, pathomorphology of the internal organs. Besides, this study includes the investigation of biological effects of metal nanoparticles after exposure of mammalian cells. Dose- and time-dependent changes in cell viability after exposure to gold hybrid nanostructures and native titanium dioxide nanoparticles were estimated by MTT test.
\end{abstract}

Keywords: Metal nanoparticles, in vitro toxicity, cell viability, MTT-test

\section{INTRODUCTION}

Metal nanoparticles are nowadays one of the most widely used nanomaterials having a number of production and practical applications [1-4]. Among them, gold hybrid nanostructures (GHNs) and titanium dioxide (IV) nanoparticles $\left(\mathrm{TiO}_{2} \mathrm{NPs}\right)$ can be mentioned as promising materials used for various biomedical purposes including targeted delivery systems, photothermal therapy, implantation, drug and vaccines development, etc. [5-9]. Using of nanoparticles as therapeutic agents raises the issue regarding their biosafety toward humans. The toxicity mechanisms of nanoparticles is now intensively investigated by a scientific community [10-12]. For this purpose, both in vivo and in vitro biological models are used [12-14].

Biological models, alternative to in vivo test systems, are widely used in the study of the toxicity of various chemical compounds [15]. One of the effective approaches for toxicological studies is the use of cell cultures (in vitro test systems). Although in vitro experiments cannot completely replace in vivo studies, they can contribute to assessing the safety of engineered nanoparticles, including hybrid nanostructures. As a rule, in vivo experiments are carried out taking into account the initial information about the toxicity of nanoparticles. In addition, animal models are used to study indicators that are not available for in vitro systems (distribution of nanomaterials in organs and tissues, their metabolism and excretion, etc.). However, in vitro systems can be effectively used as indicators of the toxicity of nanoparticles and for conducting mechanistic investigations.

A number of undoubted advantages characterizes in vitro test systems based on human and animal cell cultures: the simplicity of cell cultivation by proven methods, the possibility of visual detection of viable cells during the whole experiment using microscopic methods, and a higher reproducibility in comparison to in vivo test systems. Cost-effective and not time-consuming in vitro models allow decreasing the number of experimental animals or a complete replacing of in vivo test systems [16]. 
MTT test the is one of the most widely used methods for assessing cytotoxicity towards a large number of living cells of different cell lines exposed to xenobiotics [17]. This test is proved to be a classical approach for toxicological assessment of various compounds, including nanomaterials. The MTT assay estimates the mitochondria activity and therefore can be used for determination of the amount of living cells. The principle of the MTT test is based on the ability of the succinate dehydrogenase contained in the mitochondrial membrane of a mammalian cell to reduce the yellow salt of 3-(4,5-dimethyl-2-thiazolyl)-2,5-diphenyl-2H-tetrazolium bromide (MTT) to violet formazan crystals accumulated in the cytoplasm of living cells as a result of this reaction. Therefore, the rate of formazan crystals' accumulation in the cytoplasm represents the level of mitochondrial respiration of the cell, which is an indicator of its viability. The amount of formazan formed in the cell monolayer is proportional to the number of living cells. The effect of nanomaterials is evaluated by their inhibition of the proliferation and viability of exposed cells. The MTT test has such advantages as rapidity, high reproducibility, lack of sophisticated analytical equipment, and low cost.

This manuscript includes the results obtained as a part of the whole study directed to in vivo and in vitro investigation of biological effects of nanomaterials. Murine embryonal fibroblast (NIH-3T3) and murine monocyte/macrophage (P388-D1) cell lines were used to evaluate the cytotoxicity of core-shell GHNs and native $\mathrm{TiO}_{2} \mathrm{NPs}$ by MTT test.

\section{EXPERIMENTAL}

\subsection{Materials}

$\mathrm{TiO}_{2} \mathrm{NPs}$ of anatase form $(<25 \mathrm{~nm})$, chloroauric acid, bovine serum albumin, MTT, trypsin, streptomycin sulfate, dimethyl sulfoxide, Dulbecco's modified Eagle's medium (DMEM) were purchased from Sigma-Aldrich, USA. Goat polyclonal antibodies against mouse immunoglobulins (IgG) were purchased from Arista Biologicals, USA.

All other chemicals were of HPLC gradient grade (Sigma-Aldrich, USA, and Panreac, Spain). Milli-Q deionized water (Millipore, USA) was used for preparing solutions.

The optical density (OD) was measured at $570 \mathrm{~nm}$ with a Zenyth 3100 microplate photometer (Anthos Labtec Instruments, Austria).

\subsection{Obtaining of GHNs}

GHNs were obtained on the base of gold nanoparticles (GNPs) of $30 \mathrm{~nm}$ diameter and goat polyclonal antibodies (IgG). Conjugation GNPs with IgG was carried out as described in [18]. To obtain GHNs, the IgG concentration of $10 \mu \mathrm{g} / \mathrm{mL}$ was selected.

\subsection{Characterization of nanomaterials by transmission electron microscopy}

$\mathrm{TiO}_{2} \mathrm{NPs}$ and GHNs were dispersed in deionized water at a concentration of $0.1 \mathrm{mg} / \mathrm{ml}$. The aliquot of the obtained dispersion was dropped onto a Formvar film-coated grid and studied by transmission electron microscopy (TEM) on a JEM-100C microscope (Jeol, Japan) at an accelerating voltage of $80 \mathrm{kV}$.

\subsection{Nanomaterials dispersion protocol}

$\mathrm{TiO}_{2} \mathrm{NPs}$ and GHNs were diluted to concentrations of $250,100,50,25,10,5,1,0.5$, and $0.1 \mu \mathrm{g} / \mathrm{mL}$ with DMEM. The resulting mixtures were stirred vigorously for $10 \mathrm{~min}$ at room temperature. 


\subsection{Exposure of murine embryonal fibroblast cells (NIH-3T3) and murine monocyte/macrophage cells (P388-D1) to $\mathrm{TiO}_{2} \mathrm{NPs}$ and GHNs}

$\mathrm{NIH}-3 \mathrm{~T} 3$ and P388-D1 cells were cultured in DMEM supplemented with 10\% (vol./vol.) heat-inactivated fetal calf serum and streptomycin sulfate in concentration of $100 \mu \mathrm{g} / \mathrm{mL}$. An environment of humidified air containing $5 \% \mathrm{CO}_{2}$ was maintained at $37{ }^{\circ} \mathrm{C}$. At $85 \%$ confluence, cells were harvested using $0.25 \%$ trypsin and were subcultured into $60 \mathrm{~mm}$ dishes, 6 -well plates or 96 -well plates. Cells were allowed to attach the surface for 24 $\mathrm{h}$ prior to treatment. $\mathrm{TiO}_{2} \mathrm{NPs}$ and $\mathrm{GHNs}$ were diluted to appropriate concentrations by suspending in cell culture medium. Then, the dilutions of nanomaterials were sonicated using an ultrasound bath $(100 \mathrm{~W}, 40 \mathrm{kHz})$ at room temperature for $10 \mathrm{~min}$ to avoid their aggregation prior to administration to cells.

\subsection{Cytotoxicity evaluation experiment}

To evaluate the cytotoxicity of $\mathrm{TiO}_{2} \mathrm{NPs}$ and GHNs, cells in the log phase were seeded onto a 96-well culture plate with 5000 cells per well and incubated at $37^{\circ} \mathrm{C}$ in a $\mathrm{CO}_{2}$ incubator for $24 \mathrm{~h}$ until the cells adhered to the plate. Then, $\mathrm{TiO}_{2} \mathrm{NPs}$ or GHNs in concentrations of $250,100,50,25,10,5,1,0.5$, and $0.1 \mu \mathrm{g} / \mathrm{mL}$ were added. After 24, 48, $72 \mathrm{~h}$ incubation, cell viability was measured using the MTT assay. As a control, cell media without nanomaterials was added. For this assay, $100 \mu \mathrm{L}$ of MTT solution in concentration of $0.5 \mathrm{mg} / \mathrm{mL}$ (prepared in medium without serum) was added to the cells and incubated at $37^{\circ} \mathrm{C}$ in a $\mathrm{CO}_{2}$ incubator for $4 \mathrm{~h}$. Dimethyl sulfoxide was then used to dissolve the formazan crystals. Finally, the OD was measured at $570 \mathrm{~nm}$ using a microplate reader.

\subsection{Data analysis}

The number of living cells (as a percentage of control cells not exposed to nanomaterials) is determined by the following formula:

$\mathrm{OD}_{570 \mathrm{exp}} / \mathrm{OD}_{570 \text { control }} \times 100 \%$,

where:

OD 570 exp is an OD at $570 \mathrm{~nm}$ for cells treated with nanomaterials

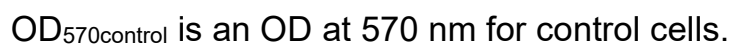

\section{RESULTS AND DISCUSSION}

\subsection{Characterization of $\mathrm{TiO}_{2} \mathrm{NPs}$ and GHNs by TEM}

The size and aggregation state of the $\mathrm{TiO}_{2} \mathrm{NPs}$ and GHNs were determined using TEM. Both samples contained electron-dense particles with well-developed facets (Figure 1).
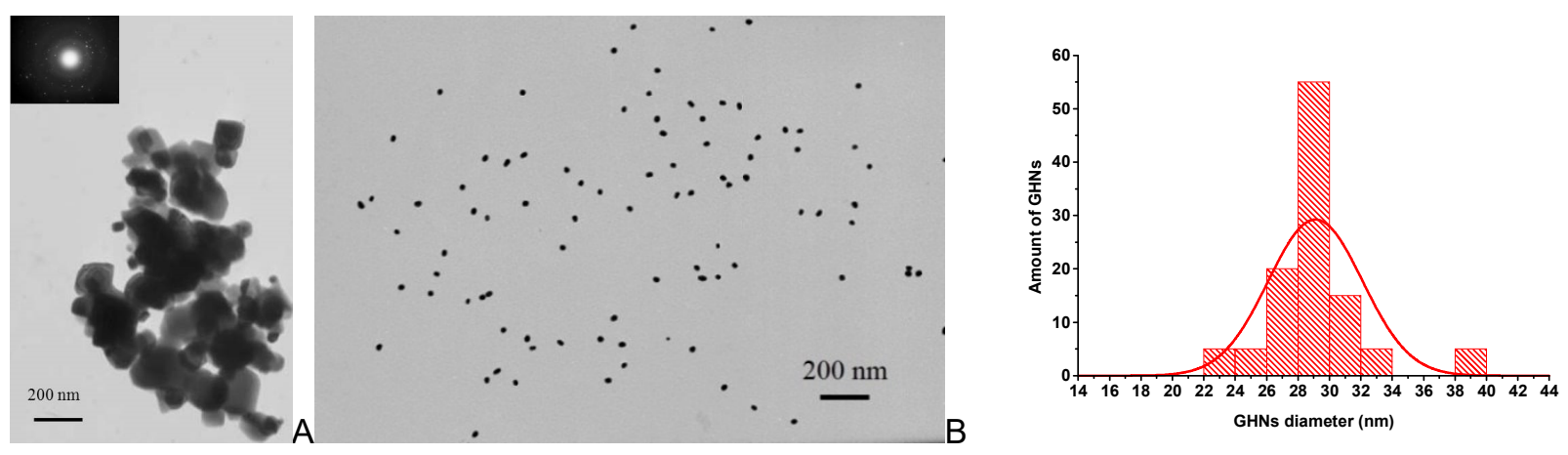

Figure 1 Microphotographs of $\mathrm{TiO}_{2} \mathrm{NPs}(\mathrm{A}), \mathrm{GHNs}(\mathrm{B})$, and GHNs size distribution (C) 
$\mathrm{TiO}_{2} \mathrm{NPs}$ was characterized by a clear contour and a high electron density. Individual spherical $\mathrm{TiO}_{2} \mathrm{NPs}$ had a diameter of approx. 20-25 $\mathrm{nm}$ and tended to form aggregates of a diameter larger than $100 \mathrm{~nm}$ in an aqueous medium (Figure 1A). The GHNs sample contained homogeneous spherical non-aggregated nanoparticles with the average diameter of $33,7 \pm 8,9 \mathrm{~nm}$ and the mean ellipticity of $1,1 \pm 0,4$ (Figures 1B, C).

\subsection{The dose- and time-dependent cytotoxicity of $\mathrm{TiO}_{2} \mathrm{NPs}$}

For evaluation of nanomaterial-induced cytotoxic effects toward cells an MTT test was used. Cell viability was assessed after incubation of NIH 3T3 and P388-D1 cells with $\mathrm{TiO}_{2}$ NPs and GHNs in concentrations of 250, $100,50,25,10,5,1,0.5$ and $0.1 \mu \mathrm{g} / \mathrm{mL}$ during 24,48 and $72 \mathrm{~h}$ as the ratio (\%) of OD values of treated cells to that of untreated ones. The results of cytotoxicity assessment after exposure to $\mathrm{TiO}_{2} \mathrm{NPs}$ are presented in Figure 2.
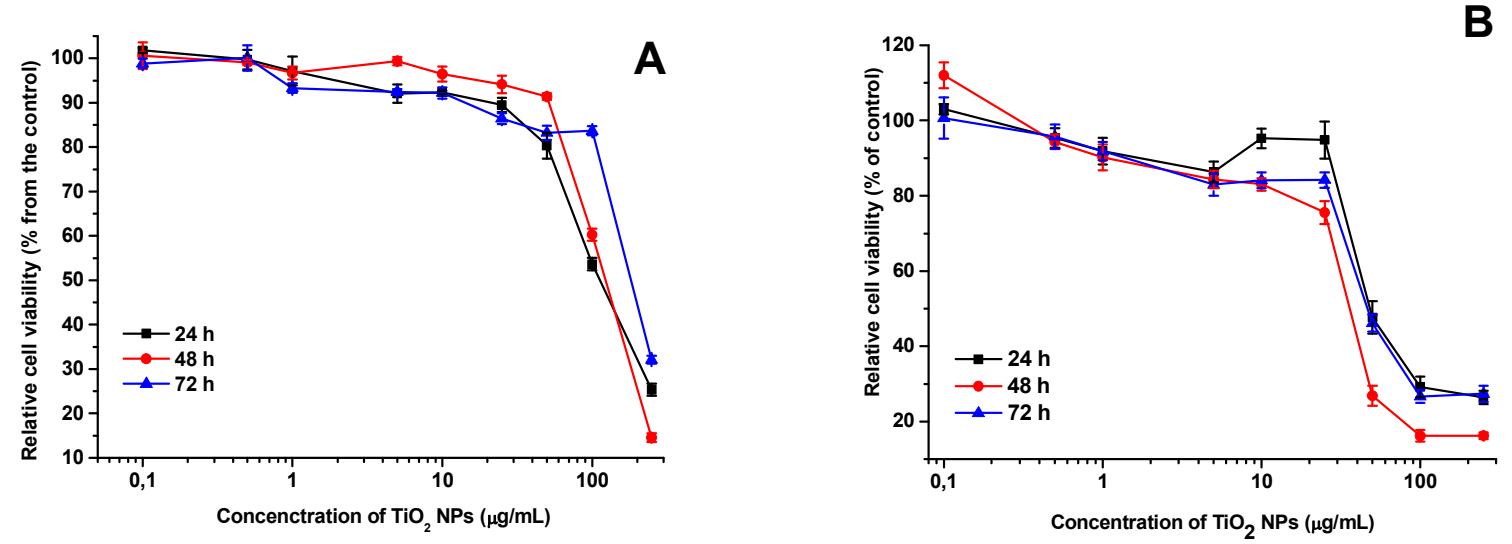

Figure 2 Viability of NIH-3T3 cells (A) and P388-D1 cells (B) after 24, 48 and $72 \mathrm{~h}$ of exposure to different concentrations of $\mathrm{TiO}_{2}$ NPs evaluated with MTT assay. Values are mean \pm standard deviation (SD) from five independent experiments

As it is evident from Figure $2 \mathrm{~A}$, the cytotoxic effect of $\mathrm{TiO}_{2} \mathrm{NPs}$ towards fibroblasts increased dosedependently. The manner of this effect is similar for 24,48 , and $72 \mathrm{~h}$ exposition. NIH $3 \mathrm{~T} 3$ cells' viability was about $80 \%$ and more after the incubation with $\mathrm{TiO}_{2} \mathrm{NPs}$ in a concentration range of $0.1-25 \mu \mathrm{g} / \mathrm{mL}$. At higher $\mathrm{TiO}_{2}$ concentrations ( 100 and $250 \mu \mathrm{g} / \mathrm{mL}$ ) cell viability dramatically decreased down to $20 \%$ and less and was characterized by the same values for different times of cell treatment. For monocyte/macrophage cells, the observed dependency was quite comparable (Figure 2B). Cell viability was above $80 \%$ after exposition to $\mathrm{TiO}_{2} \mathrm{NPs}$ in a concentration range of $0.1-50 \mu \mathrm{g} / \mathrm{mL}$. Higher concentrations $(100$ and $250 \mu \mathrm{g} / \mathrm{mL}$ ) cause extensive cell death resulting in only $10-30 \%$ of live monocytes/macrophages. The described effect was similar for all incubation periods.

\subsection{The dose- and time-dependent cytotoxicity of GHNs}

The cytotoxic effect of GHNs against fibroblasts and monocytes/macrophages evaluated by MTT test are presented in Figure 3.

The data presented in Figure $\mathbf{3 A}$ demonstrate the dose-dependent cytotoxic effect of GHNs with respect to $\mathrm{NIH}-3 \mathrm{~T} 3$ cell line. A decrease in cell viability was observed at all exposure times studied. In the concentration range of $0.1-10 \mu \mathrm{g} / \mathrm{mL}$, the amount of living fibroblasts was $80 \%$ and even higher (up to $100 \%$ ). After exposition of cells to GHNs at the middle dose range $(25-50 \mu \mathrm{g} / \mathrm{mL})$, the percentage of living cells was lower: $\sim 55-75 \%$ of cells remained viable after the exposure. At high concentrations of GHNs (100 and $250 \mu \mathrm{g} / \mathrm{mL}$ ), cell viability declined sharply to $20-30 \%$ or less. 

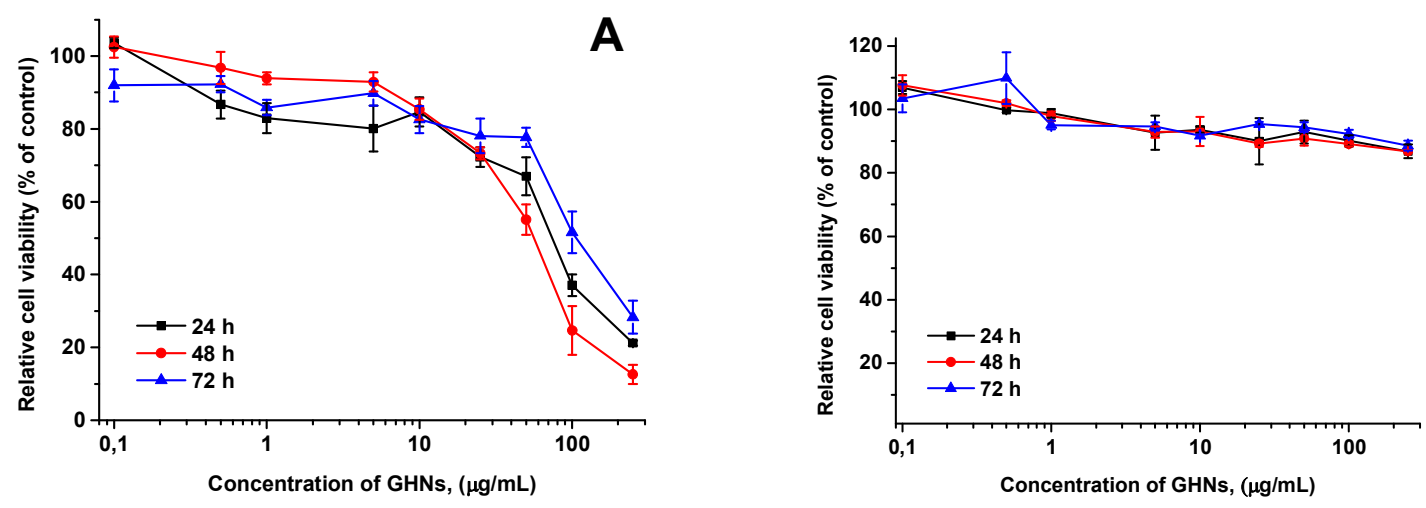

B

Figure 3 Viability of the NIH-3T3 cells (A) and P388-D1 cells (B) after 24,48 and $72 \mathrm{~h}$ of exposure to different concentrations of GHNs evaluated with MTT assay. Values are mean \pm standard deviation (SD)

from five independent experiments

For GHNs studied, a time-dependent cytotoxic effect was investigated in 24-48-72 h time interval. The percentage of living cells was reduced mainly upon incubation in the 24-48 $\mathrm{h}$ interval (Figure 3A). It should be noted that for middle and high doses ( $25 \mu \mathrm{g} / \mathrm{mL}$ and more), this effect was most pronounced. The cytotoxicity of GHNs after exposure at low doses didn't have a time-dependent manner: the amount of survived cells reached $100 \%$.

For the P388-D1 cell line, the observed cytotoxic effects differed from those detected for the NIH-3T3 cell line (Figure 3B). As it can be seen from the presented data, after exposure to GHNs in the low and middle concentration ranges $(0.1-50 \mu \mathrm{g} / \mathrm{mL})$, the cell viability level was about $90 \%$ and higher and practically did not depend upon the exposure time (24-48-72 h). Incubation with GNHs at higher concentrations (100 and $250 \mu \mathrm{g} / \mathrm{mL}$ ) caused an increase in cell death, but the level of living cells dropped to only $80 \%$. The described effect was observed for all time periods of exposure. Therefore, after exposure to GHNs the survival rate of murine monocyte/macrophage cells was higher than that of murine fibroblast cells. The time-dependent cytotoxic effect was less pronounced than for fibroblasts.

\section{CONCLUSION}

Overall, the cytotoxic effect of GHNs and native $\mathrm{TiO}_{2} \mathrm{NPs}$ on mammalian cells of two cell lines was studied. A dose- and time-dependent effect on cell viability was demonstrated using the MTT test. Difference in the sensitivity of cell lines to the studied nanomaterials was demonstrated. A safe in vitro dosage was determined for both nanostructures.

\section{ACKNOWLEDGEMENTS}

This research was financially supported by the Ministry of Science and High Education of the Russian Federation; state contract 14.613.21.0086 beginning on November 27, 2018; unique identifier of the project: RFMEFI61318X0086.

\section{REFERENCES}

[1] VIO, V., MARCHANT, M.J., ARAYA, E. and KOGAN, M.J. Metal nanoparticles for the treatment and diagnosis of neurodegenerative brain diseases. Current harmaceutical design. 2017. vol. 23, no. 13, pp.1916-1926.

[2] ZHANG, C., YAN, L., GU, Z. and ZHAO, Y. Strategies based on metal-based nanoparticles for hypoxic-tumor radiotherapy. Chemical Science. 2019. vol. 10, no. 29, pp. 6932-6943. 
[3] HOSEINZADEH, E., MAKHDOUMI, P., TAHA, P., HOSSINI, H., STELLING, J., KAMAL, M.A. and ASHRAF, G.M. A review on nano-antimicrobials: metal nanoparticles, methods and mechanisms. Current Drug Metabolism. 2017. vol. 18, no. 2, pp. 120-128.

[4] CABUZU, D., CIRJA, A., PUIU, R. and GRUMEZESCU, A.M. Biomedical applications of gold nanoparticles. Current Topics in Medicinal Chemistry. 2015. vol. 15, no. 16, pp. 1605-1613.

[5] DARAEE, H., EATEMADI, A., ABBASI, E., FEKRI AVAL, S., KOUHI, M. and AKBARZADEH, A. Application of gold nanoparticles in biomedical and drug delivery. Artificial Cells, Nanomedicine, and Biotechnology. 2016. vol. 44, no. 1, pp. 410-422.

[6] PENG, J., LIANG, X. Progress in research on gold nanoparticles in cancer management. Medicine. 2019. vol. 98, no. 18. Pp. e15311.

[7] CHUGH, H., SOOD, D., CHANDRA, I., TOMAR, V., DHAWAN, G. and CHANDRA, R. Role of gold and silver nanoparticles in cancer nano-medicine. Artificial Cells, Nanomedicine, and Biotechnology. 2018. vol. 46, no. sup1, pp. 1210-1220.

[8] YOUSSEF, Z., VANDERESSE, R., COLOMBEAU, L., BAROS, F., ROQUES-CARMES, T., FROCHOT, C., WAHAB, H., TOUFAILY, J., HAMIEH, T. and ACHERAR, S. The application of titanium dioxide, zinc oxide, fullerene, and graphene nanoparticles in photodynamic therapy. Cancer Nanotechnology. 2017. vol. 8, no. 1. pp. 6.

[9] KUMAR, N., CHAUHAN, N.S., MITTAL, A. and SHARMA, S. TiO 2 and its composites as promising biomaterials: a review. Biometals: an International Journal on the Role of Metal lons in Biology, Biochemistry, and Medicine. 2018. vol. 31, no. 2, pp. 147-159.

[10] SHAKEEL, M., JABEEN, F., SHABBIR, S., ASGHAR, M.S., KHAN, M.S. and CHAUDHRY, A.S. Toxicity of nanotitanium dioxide $\left(\mathrm{TiO}_{2}-\mathrm{NP}\right)$ through various routes of exposure: a review. Biological Trace Element Research. 2016. vol. 172, no, 1, pp. 1-36.

[11] SHI, H., MAGAYE, R., CASTRANOVA, V. and ZHAO, J. Titanium dioxide nanoparticles: a review of current toxicological data. Particle and Fibre Toxicology. 2013. vol. 10, no. 15.

[12] LOPEZ-CHAVES, C., SOTO-ALVAREDO, J., MONTES-BAYON, M., BETTMER, J., LLOPIS, J. and SANCHEZGONZALEZ, C. Gold nanoparticles: distribution, bioaccumulation and toxicity. In vitro and in vivo studies. Nanomedicine: Nanotechnology, Biology, and Medicine. 2018. vol. 14, no. 1, pp. 1-12.

[13] BAILlY, A.L., CORREARD, F., POPOV, A., TSELIKOV, G., CHASPOUL, F., APPAY, R., AL-KATTAN, A., KABASHIN, A.V., BRAGUER, D. and ESTEVE, M.A. In vivo evaluation of safety, biodistribution and pharmacokinetics of laser-synthesized gold nanoparticles. Scientific Reports. 2019. vol. 9, no. 1, pp. 12890.

[14] DE MATTEIS, V. Exposure to inorganic nanoparticles: routes of entry, immune response, biodistribution and in vitro/in vivo toxicity evaluation. Toxics. 2017. vol. 5, no. 4.

[15] AJDARY, M., MOOSAVI, M.A., RAHMATI, M., FALAHATI, M., MAHBOUBI, M., MANDEGARY, A., JANGJOO, S., MOHAMMADINEJAD, R. and VARMA, R.S. Health concerns of various nanoparticles: a review of their in vitro and in vivo toxicity. Nanomaterials. 2018. vol. 8, no. 9.

[16] CLIPPINGER, A.J., ALLEN, D., BEHRSING, H., BERUBE, K.A., BOLGER, M.B., CASEY, W., DELORME, M., GACA, M., GEHEN, S.C. and GLOVER, K. Pathway-based predictive approaches for non-animal assessment of acute inhalation toxicity. Toxicology in Vitro: an International Journal Published in Association with BIBRA. 2018. vol. 52, pp. 131-145.

[17] BAHADAR, H., MAQBOOL, F., NIAZ, K. and ABDOLLAHI, M. Toxicity of nanoparticles and an overview of current experimental models. Iranian Biomedical Journal. 2016. vol. 20, no. 1, pp. 1-11.

[18] HENDRICKSON, O.D., ZVEREVA, E.A., SHANIN, I.A., ZHERDEV, A.V. and DZANTIEV, B.B. Development of a multicomponent immunochromatographic test system for the detection of fluoroquinolone and amphenicol antibiotics in dairy products. Journal of the Science of Food and Agriculture. 2019. vol. 99, no, 8, pp. 3834-3842. 